\title{
Fatal deep venous thrombosis and pulmonary embolism secondary to melioidosis in China: case report and literature review
}

\author{
Hua $\mathrm{Wu}^{1}$, Dongliang Huang ${ }^{2}$, Biao $\mathrm{Wu}^{3}$, Mengjie $\mathrm{Pan}^{4}$ and Binghuai $\mathrm{Lu}^{5,6,7^{*}}$ (D)
}

\begin{abstract}
Background: Burkholderia pseudomallei is a gram-negative bacterium and the causative pathogen of melioidosis, which manifests a variety ranges of infection symptoms. However, deep venous thrombosis (DVT) and pulmonary embolism (PE) secondary to bacteremic melioidosis are rarely documented in the literature. Herein, we reported a fatal case of melioidosis combined with DVT and PE.

Case presentation: A 54-year-old male construction worker and farmer with a history of diabetes was febrile, painful in left thigh, swelling in left lower limb, with chest tightness and shortness of breath for 4 days. He was later diagnosed as DVT of left lower extremity and PE. The culture of his blood, sputum and bone marrow samples grew B. pseudomallei. The subject was administrated with antibiotics (levofloxacin, cefoperazone/tazobactam, and imipenem) according to antimicrobial susceptibility testing and low molecular heparin for venous thrombosis. However, even after appropriate treatment, the patient deteriorated rapidly, and died 2 weeks after admission.

Conclusions: This study enhanced awareness of the risk of B. pseudomallei bloodstream infection in those with diabetes. If a patient has predisposing factors of melioidosis, when DVT is suspected, active investigation and multiple therapeutic interventions should be implemented immediately to reduce mortality rate.
\end{abstract}

Keywords: Burkholderia pseudomallei, Melioidosis, Deep venous thrombosis, Pulmonary embolism

\section{Background}

Burkholderia pseudomallei, a gram-negative bacterium commonly found in soil and water, is the infective pathogen of melioidosis in southeast Asia and northern Australia [1, 2]. Southern China has been in the expanded endemic zone of melioidosis [3-5]. Melioidosis involves almost any part of the body, with its clinical manifestation ranging from acute septicemia, respiratory tract infection, to chronic cutaneous infection. It is also called the great mimicker, as its pathogenesis and

\footnotetext{
* Correspondence: zs25041@126.com

${ }^{5}$ Laboratory of Clinical Microbiology and Infectious Diseases, Department of Pulmonary and Critical Care Medicine, China-Japan Friendship Hospital, No 2, East Yinghua Road, Chaoyang District, Beijing 100029, China

${ }^{6}$ Center for Respiratory Diseases, China-Japan Friendship Hospital, No 2, East

Yinghua Road, Chaoyang District, Beijing 100029, China

Full list of author information is available at the end of the article
}

clinical features might present like tuberculosis or brucellosis $[6,7]$.

Furthermore, there are some predisposing risk factors for melioidosis, including smoking, diabetes, occupation, and history of exposure to contaminated soil or water prior to their illness $[3,8,9]$. Deep venous thrombosis (DVT) and pulmonary embolism (PE) caused by B. pseudomallei will reinforce the high mortality rate associated with this infection, but rarely documented in the literature $[10,11]$. Herein, we reported a fetal case of DVT and PE secondary to bacteremic melioidosis in a diabetic farmer in mainland China alongside a literature review of B. pseudomallei-caused venous thrombosis.

(c) The Author(s). 2019 Open Access This article is distributed under the terms of the Creative Commons Attribution 4.0 International License (http://creativecommons.org/licenses/by/4.0/), which permits unrestricted use, distribution, and reproduction in any medium, provided you give appropriate credit to the original author(s) and the source, provide a link to the Creative Commons license, and indicate if changes were made. The Creative Commons Public Domain Dedication waiver (http://creativecommons.org/publicdomain/zero/1.0/) applies to the data made available in this article, unless otherwise stated. 


\section{Case presentation}

\section{Medical history}

A 54-year-old male construction worker and farmer, a resident in Sanya city, Hainan province, was admitted to Hainan General Hospital on July 14, 2012, and complained of chills, fever, cough, chest tightness, pain in left thigh and popliteal fossa, and left lower limb swelling for 4 days. Ultrasonography showed a slightly stronger echo in his left common femoral vein, revealing venous thrombosis. Imaging findings of X-ray on July 14 showed that flaky blurred shadows with multiple small patches scattered in bilateral lungs, with uneven density and illdefined boundary (Fig. 1a). Furthermore, computed tomography (CT) on July 17 showed the mildly-enhanced irregular nodule with the size of $1.5 \times 1.7 \mathrm{~cm}$ in the left upper. The multiple point- and strip-like lesions scattered in the lower lobes (Fig. 1b-e). The contrast-enhanced CT scan demonstrated strip-like filling defect in the left and right pulmonary arteries and their branches (Fig. 1f). The bilateral pleural effusion was revealed and no abnormality was discovered in the structure of the chest wall. Moreover, in Fig. 1a, chest X-ray revealed multiple nodular opacities in bilateral lungs (including retrocardiac area), in Fig. 1b, c, and e, chest CT revealed multiple nodular opacities in bilateral lungs, and in Fig. 1d showed a peripheral wedge-shape opacity in right upper lobe. Taken together,

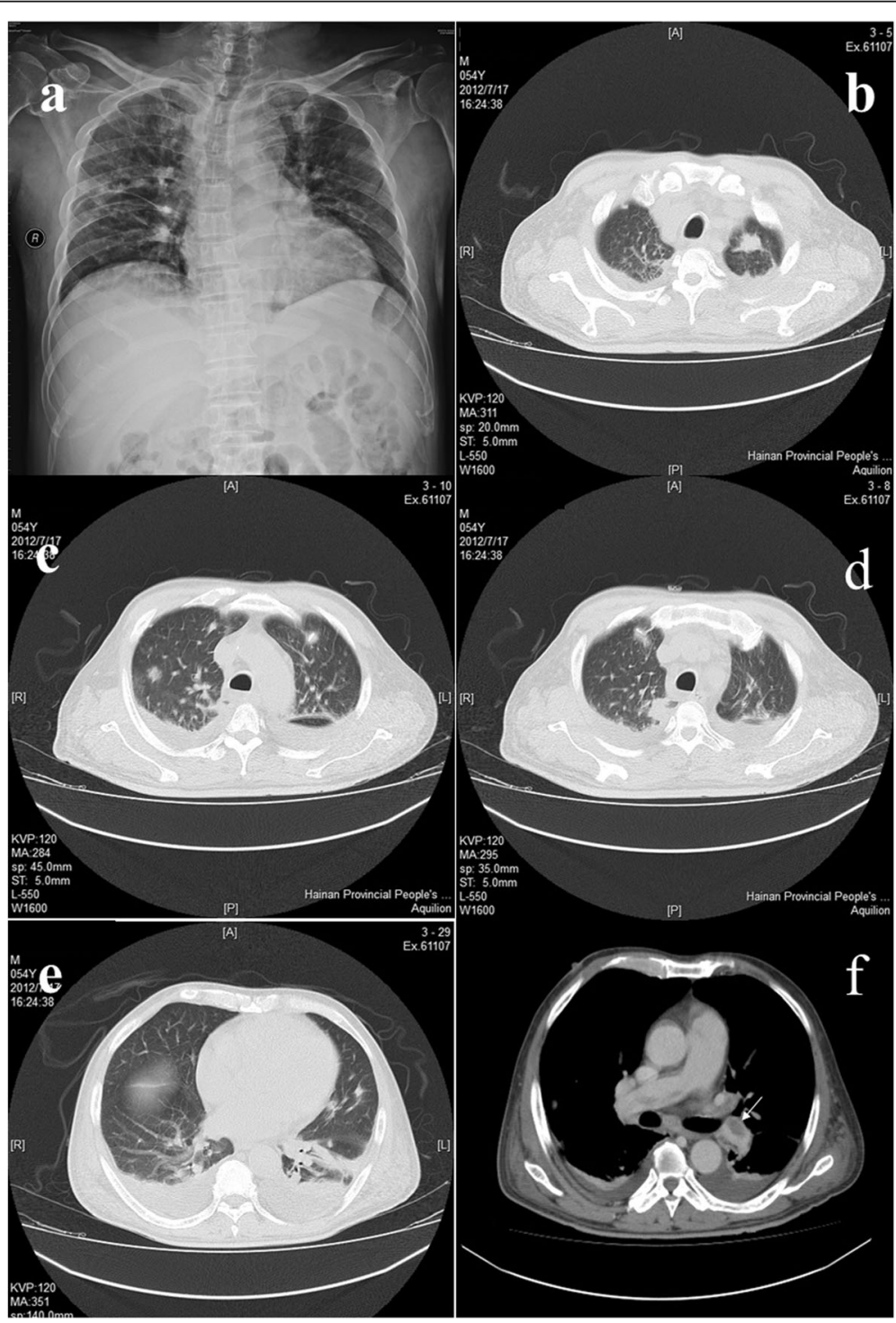

Fig. 1 An X-ray image a: flaky blurred shadows with multiple small patches distributed in bilateral lungs with uneven density and ill-defined boundary; b-e pulmonary CT images: the enhanced irregular nodule in the left upper, and multiple point- and strip-like lesions scattered in the lower lobes. $\mathbf{f}$ contrast-enhanced CT: strip-like filling defect in the bilateral pulmonary arteries and their branches. Furthermore, the bilateral pleural effusion was revealed and no abnormality was discovered in the structure of the chest wall 
these hinted the occurrence of septic PE in our patient. There were slightly larger mediastinal lymph nodes, bilateral pleural effusion, low-density lesions in the right lower kidney, and splenomegaly with multiple low-density lesions. His plasma D-dimers were $8.24 \mu \mathrm{g} / \mathrm{ml}$ (normal range $\leqq 0.5 \mu \mathrm{g} / \mathrm{ml}$ ). Therefore, the diagnosis of DVT at left lower extremity and PE was made. At admission, the patient's body temperature rose up to $39^{\circ} \mathrm{C}$, and his blood examinations, including leucocyte, neutrophil percentage and C-reactive protein, elevated significantly over reference ranges. He was suspected of severe infection, and levofloxacin and cephalosporin were empirically administrated the day after his hospitalization. The patient refused the implantation of inferior vena cava filter. After July 17, he was treated with daily subcutaneous injections of low molecular weight heparin to reduce the risk of further thrombosis. Despite anticoagulation and antimicrobial therapy, the patient presented continuous high fever, chest tightness, cough and expectoration, shortness of breath, and antibiotic was transferred to cefoperazone/tazobactam.

His coagulation results were normal except for the elevated fibrinogen level $(4.17 \mathrm{~g} / \mathrm{L}$, normal rang $2 \sim 4 \mathrm{~g} / \mathrm{L})$. Blood examination demonstrated hyperglycemia (blood glucose $7.98 \mathrm{mmol} / \mathrm{L}$, normal range $3.89 \sim 6.11 \mathrm{mmol} / \mathrm{L}$ ) and hyperlipemia (triglyceride $2.59 \mathrm{mmol} / \mathrm{L}$, normal range $0.33 \sim 1.69 \mathrm{mmol} / \mathrm{L}$ ), but antibody examinations for human immune deficiency virus, hepatitis $B$ virus and hepatitis $C$ virus were all negative. Expectorated sputum smear revealed a large amount of polymorphonuclear leucocytes and gram-negative bacilli. On July18 to 22, his blood, sputum and bone marrow grew B. pseudomal$l e i$, respectively. Antimicrobial susceptibility testing (AST) showed that the strain was susceptible to all antimicrobial agents with breakpoint value in CLSI.

On July 20, the patient began receiving antimicrobial therapy of imipenem. However, 4 days later, his condition dramatically deteriorated, and presented as heart failure, renal failure and persistent high fever (up to $40.1^{\circ} \mathrm{C}$ ). On July 25 , his family members received the medical crisis notice of life-threatening respiratory and circulatory failure. Considering the low probability of his survival, his family decided to take him home in accordance to the local customs of not dying in hospital. Without proper treatment the patient died 3 days later after he was discharged.

\section{Microbiologic test}

After $24 \mathrm{~h}$ of incubation on blood agar at $37^{\circ} \mathrm{C}$ in a $5 \%$ $\mathrm{CO}_{2}$ atmosphere, the B. pseudomallei $\mathrm{B} 86$ grew into round, wet, convex, non-hemolytic, gray-white colonies, with $1 \mathrm{~mm}$ in size. But after another $24 \mathrm{~h}$, the colonies turned dry, flat, a little hemolytic, and yellow with a little metallic luster, and with the smell of earthy mildew. After $72 \mathrm{~h}$, the hemolytic zone, metallic luster and smell became stronger, colonies wrinkled as wheel-shaped (Fig. 2a-c). Phenotypic identification by DL-96NE (Zhuhai DL biotech, China) revealed B. pseudomallei, and the identification rate was $99.5 \%$. AST was performed using E-test method (Liofilchem, Italy), the MIC results were as follows: susceptible to imipenem (MIC: $0.5 \mu \mathrm{g} / \mathrm{ml}$ ), ceftazidim (MIC: $1 \mu \mathrm{g} / \mathrm{ml}$ ), amoxicillin/clavulanate (MIC: $2 \mu \mathrm{g} / \mathrm{ml}$ ), doxycycline (MIC: $2 \mu \mathrm{g} / \mathrm{ml}$ ), and trimethoprim/ sulfamethoxazole (MIC: $2 \mu \mathrm{g} / \mathrm{ml}$ ).

\section{Identification by $16 \mathrm{~S}$ rRNA sequencing and multilocus sequence typing (MLST) of BP86}

To genetically characterize the isolate, the $16 \mathrm{~S}$ rRNA sequencing was conducted. Sequence analysis of the 1385 bp-segment of 16S rRNA gene of BP86 demonstrated an identity of 99.93\% with B. pseudomallei K96243 (GenBank accession no. NC_006351.1). The whole genome of the pathogen was also sequenced using a whole-genome shotgun strategy based on the Illumina HiSeq platform. The selected optimal assembly results were compared with the seven housekeeping genes of B. pseudomallei for MLST by reference to https://pubmlst.org/bpseudomallei/, and the determined sequence type of BP86 was ST 46.

\section{Discussion and conclusions}

B. pseudomallei is the pathogen of melioidosis, an infectious disease involving almost every system all over the body with complicated clinical characteristics. Melioidosis is generally thought to be epidemic in tropical and sub-tropical zone, but recently, it is speculated that it is distributed more widely beyond the tropics based on increased case reports and predictive modelling studies [12]. Southern China, especially Hainan province, is one of the additional endemic areas $[1,5]$. As reported by Zheng $\mathrm{X}$ et al., there are approximately 20 to 30 cultureconfirmed melioidosis cases in Hainan General Hospital [5]. Between 2002 and 2013, in another research in Hainan province, not including the cases in Hainan General Hospital, 170 cases of melioidosis were documented, and the most common presentations were pneumonia and bacteremia [4].

B. pseudomallei is found in soil and stagnant water in endemic regions, and it usually invades the epithelial cells of the mucosal surface or skin and then spread to others [12-16]. Diabetes mellitus is the most common predisposing factor of melioidosis, and more than $50 \%$ of the world's melioidosis patients are diabetic $[8,9]$. In the present study, our patient was a diabetic construction worker and farmer living in the endemic area, and therefore, the most possible way of being infected might be via percutaneous inoculation or inhalation of contaminated soil or water in the environment [14].

Melioidosis has multiple clinical manifestations, including acute severe sepsis, septic shock, infectious multiple 

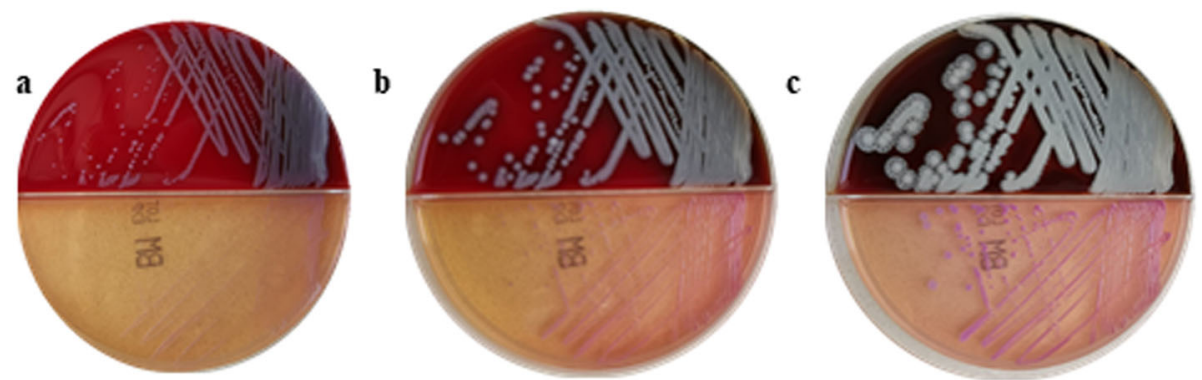

Fig. 2 a-c B. pseudomallei colonies after $24 \mathrm{~h}$ (a), $48 \mathrm{~h}$ (b) and 72 (c) of incubation on blood and MacConkey agar, respectively

organ failure, and skin and soft tissue infections. In addition to the symptoms of common bacterial infections, melioidosis is often misdiagnosed as tuberculosis or quite similar to cancer, thus it is called the remarkable imitator [3]. Few thrombosis cases caused by melioidosis were reported. A review of the medical literature was performed through PubMed using the following combination of MeSH terms: (melioidosis OR Burkholderia pseudomallei OR thrombosis) (https://www.ncbi.nlm.nih.gov/pubmed), only six cultured-confirmed cases of melioidosis thrombosis could be found, and three of which were dural venous sinus thrombosis $[10,17,18]$, two cases were splenic vein thrombosis $[19,20]$, and one was portal vein thrombosis [11]. Characteristics of the melioidosis with venous thrombosis, including predisposing factors, clinical presentation, treatment and outcome are detailed in Table 1. Inflammation has been regarded as a common pathway through which various risk factors trigger vein thrombosis. The sepsis could release inflammatory mediators, cause endothelial injury, and stimulate the production of plasminogen activator inhibitor-1 (PAI-1), resulting in abnormal function of coagulation-anticoagulation-

Table 1 Literature review of melioidosis thrombosis cases with summary of predisposing factors, clinical presentation, treatment and outcome

\begin{tabular}{|c|c|c|c|c|c|c|c|}
\hline Reference & $2006[10]$ & 2007 [16] & 2018 [17] & $2010[18]$ & 2015 [19] & 2017 [11] & Our data \\
\hline $\begin{array}{l}\text { Cases } \\
\text { number }\end{array}$ & 1 & 1 & 1 & 1 & 1 & 1 & 1 \\
\hline $\begin{array}{l}\text { Country/ } \\
\text { Area }\end{array}$ & Thailand & Malaysia & India & Brunei & France & Thailand & China \\
\hline $\begin{array}{l}\text { Age(y)/ } \\
\text { Gende }\end{array}$ & 42/male & $33 /$ male & 23/male & 48/male & 52/male & 54/male & 54/male \\
\hline $\begin{array}{l}\text { Underlying } \\
\text { disease }\end{array}$ & $\begin{array}{l}\text { diabetes, mild } \\
\text { alcoholic cirrhosis }\end{array}$ & NA & NA & diabetes & NA & diabetes & diabetes \\
\hline Presentation & $\begin{array}{l}\text { fever, headache, left } \\
\text { hemiparesis, focal } \\
\text { seizure, increased } \\
\text { intracranial pressure }\end{array}$ & $\begin{array}{l}\text { fever, seizures, } \\
\text { altered } \\
\text { conscious level } \\
\text { and neck } \\
\text { stiffness, }\end{array}$ & $\begin{array}{l}\text { diplopia, } \\
\text { decreased } \\
\text { hearing }\end{array}$ & $\begin{array}{l}\text { fever, rigor, } \\
\text { abdominal pain, } \\
\text { loss of appetite, } \\
\text { weight loss }\end{array}$ & $\begin{array}{l}\text { fever with chills, } \\
\text { palpitations and } \\
\text { an unproductive } \\
\text { cough. }\end{array}$ & $\begin{array}{l}\text { febrile, } \\
\text { icteric, } \\
\text { dehydrated }\end{array}$ & $\begin{array}{l}\text { febrile, painful in left } \\
\text { thigh with left lower } \\
\text { limb swelling, chest } \\
\text { tightness, shortness of } \\
\text { breath }\end{array}$ \\
\hline $\begin{array}{l}\text { Thrombus } \\
\text { site }\end{array}$ & dural sinus & $\begin{array}{l}\text { superior } \\
\text { sagittal sinus }\end{array}$ & $\begin{array}{l}\text { dural venous } \\
\text { sinus }\end{array}$ & splenic vein & $\begin{array}{l}\text { splenic vein, right } \\
\text { portion of the } \\
\text { portal vein }\end{array}$ & $\begin{array}{l}\text { left portal } \\
\text { vein }\end{array}$ & left lower extremity \\
\hline $\begin{array}{l}\text { Sources } \\
\text { Identification }\end{array}$ & blood & blood & $\begin{array}{l}\text { brain tissue } \\
\text { biopsy }\end{array}$ & $\begin{array}{l}\text { blood, pancreas, } \\
\text { lung, spleen, liver }\end{array}$ & blood, sputum & blood & $\begin{array}{l}\text { blood, sputum, bone } \\
\text { marrow }\end{array}$ \\
\hline $\begin{array}{l}\text { Antibiotic } \\
\text { therapy }\end{array}$ & ceftazidime & NA & $\begin{array}{l}\text { ceftazidime, } \\
\text { cotrimoxazole }\end{array}$ & $\begin{array}{l}\text { ceftazidime, } \\
\text { amoxicillin- } \\
\text { clavulanic acid, } \\
\text { doxycycline, co- } \\
\text { trimoxazole }\end{array}$ & $\begin{array}{l}\text { ceftazidime, } \\
\text { meropenem, co- } \\
\text { trimoxazole, } \\
\text { amoxicillin- } \\
\text { clavulanic acid, }\end{array}$ & $\begin{array}{l}\text { ceftazidime, } \\
\text { amoxicillin- } \\
\text { clavulanic } \\
\text { acid }\end{array}$ & $\begin{array}{l}\text { levofloxacin, } \\
\text { cefoperazone/ } \\
\text { tazobactam, imipenem }\end{array}$ \\
\hline $\begin{array}{l}\text { Other } \\
\text { therapy }\end{array}$ & $\begin{array}{l}\text { antiepileptic drug } \\
\text { and anticoagulant }\end{array}$ & $\begin{array}{l}\text { craniectomy } \\
\text { and drainage } \\
\text { of the abscess }\end{array}$ & anticoagulant & no other therapy & anticoagulant & anticoagulant & $\begin{array}{l}\text { anticoagulant (low } \\
\text { molecular heparin) }\end{array}$ \\
\hline Outcome & recovered & recovered & $\begin{array}{l}\text { no } \\
\text { improvement }\end{array}$ & recovered & recovered & recovered & died \\
\hline
\end{tabular}


fibrinolysis system [21, 22]. For melioidosis sepsis in particular, inflammatory response might result in the reduction of the endothelial modulators protein $\mathrm{C}$ and antithrombin [10, 23]. In line with the study by Hernández-Espinosa $\mathrm{D}$ et al., diabetes is not just the most common risk factor of melioidosis, but also might activate the activity of protein kinase $\mathrm{C}$ and aldose reductase, and lead to thrombosis [24]. Our subject was a diabetic patient with a badly-controlled blood glucose level. Furthermore, according to our review results, three out of six $(50 \%)$ patients with vein thrombosis were diabetic. In line with previous studies [14, 20, 25], a male preponderance was documented in melioidosis. All melioidosis patients with thrombosis in our reviewed cases were male.

Five of six reported and our case B. pseudomallei strains were isolated from blood culture, and in an Indian young male, the microorganism was recovered from brain tissue biopsy [18]. Furthermore, in our case, bone marrow also grew $B$. pseudomallei. Melioidosis has a case-fatality rate as high as $40 \%[3,25]$, and the prognosis may be worse if combined with DVT/PE. However, to our surprise, in line with our review, five cases in literature with DVT/PE recovered and discharged home and one remained unchanged. Unfortunately, our patien was complicated with $\mathrm{PE}$, and died afterwards, even timely anticoagulation and susceptible antibiotics were used.

In summary, to the best of our knowledge, this is the first report of PE/DVT secondary to B. pseudomallei infection. Physicians and laboratories in endemic areas should be aware of this potentially emerging disease. DVT/PE or other thrombosis should be taken into account when patients have predisposing factors or culture-confirmed melioidosis, especially if the patient has pain and swelling in the limb and chest pain.

\section{Abbreviations \\ AST: Antimicrobial susceptibility testing; CT: Computed tomography; DVT: Deep venous thrombosis; MLST: Multilocus sequence typing; PE: Pulmonary embolism}

\section{Acknowledgments}

We are grateful to Dr. Xiao Zhanxiang, director of Vascular Surgery Department, Hainan General Hospital, for his generous help to this study.

\section{Authors' contributions}

$\mathrm{HW}, \mathrm{DH}, \mathrm{BW}$, and MP isolated bacteria and performed the laboratory measurements. HW and BL made substantial contributions to conception and design, and drafted the manuscript. All authors read and approved the final manuscript.

\section{Funding}

We gratefully acknowledge funding from National Key Research and Development Program of China (Grant No. 2018YFC1200102), Key Research and Development Program of Hainan Province (Grant No. ZDYF2018113), and Beijing Municipal Science \& Technology Commission, PR China (No. Z171100001017118). The funding bodies had no role in the design of the study or collection, analysis, processing or interpretation of data or in writing the manuscript.

\section{Availability of data and materials}

All the data and material involved in the current study are available from the corresponding author on reasonable request.

\section{Ethics approval and consent to participate}

The institutional review boards at the Hainan general hospital approved the study protocol.

\section{Consent for publication}

Written informed consent was obtained from the patient's direct relative for publication of this study. A copy of the written consent is available for review by the Editor of this journal.

\section{Competing interests}

The authors declare that they have no competing interests.

\section{Author details}

'Department of Laboratory Medicine, Hainan General Hospital, No 19 Xiuhua Street, Xiuying District, Haikou 570311, China. ${ }^{2}$ Department of Emergency, Hainan Armed Police Corps Hospital, Wenmingdong Road, Meilan District, Haikou 570203, China. ${ }^{3}$ Department of Infectious Diseases, Hainan General Hospital, No 19 Xiuhua Street, Xiuying District, Haikou 570311, China.

${ }^{4}$ Department of Radiology, Hainan General Hospital, No 19 Xiuhua Street, Xiuying District, Haikou 570311, China. ${ }^{5}$ Laboratory of Clinical Microbiology and Infectious Diseases, Department of Pulmonary and Critical Care Medicine, China-Japan Friendship Hospital, No 2, East Yinghua Road, Chaoyang District, Beijing 100029, China. ${ }^{6}$ Center for Respiratory Diseases, China-Japan Friendship Hospital, No 2, East Yinghua Road, Chaoyang District, Beijing 100029, China. ${ }^{7}$ National Clinical Research Center of Respiratory

Diseases, No 2, East Yinghua Road, Chaoyang District, Beijing 100029, China.

Received: 25 August 2019 Accepted: 11 November 2019

Published online: 21 November 2019

\section{References}

1. Limmathurotsakul D, Golding N, Dance DAB, Messina JP, Pigott DM, Moyes CL, Rolim DB, Bertherat E, Day NPJ, Peacock SJ, et al. Predicted global. distribution of Burkholderia pseudomallei and burden of melioidosis. Nat Microbiol. 2016;1(1). https://doi.org/10.1038/NMICROBIOL.2015.8.

2. Cheng AC, Currie BJ. Melioidosis: epidemiology, pathophysiology, and management. Clin Microbiol Rev. 2005;18(2):383-416.

3. Wiersinga WJ, Currie BJ, Peacock SJ. Melioidosis. N Engl J Med. 2012;367(11): 1035-44.

4. Fang Y, Chen H, Li Y, Li Q, Ye Z, Mao XH. Melioidosis in Hainan, China: a restrospective study. Trans R Soc Trop Med Hyg. 2015;109(10):636-42.

5. Zheng X, Xia Q, Xia L, Li W. Endemic melioidosis in southern China: past and present. Trop Med Infect Dis. 2019;4(1). https://doi.org/10.3390/ tropicalmed4010039.

6. Yee KC, Lee MK, Chua CT, Puthucheary SD. Melioidosis, the great mimicker: a report of 10 cases from Malaysia. J Trop Med Hyg. 1988;91(5):249-54.

7. Doker TJ, Quinn CL, Salehi ED, Sherwood JJ, Benoit TJ, Glass Elrod M, Gee JE, Shadomy SV, Bower WA, Hoffmaster AR, et al. Fatal Burkholderia pseudomallei infection initially reported as a Bacillus species, Ohio, 2013. Am J Trop Med Hyg. 2014;91(4):743-6.

8. Currie BJ, Jacups SP, Cheng AC, Fisher DA, Anstey NM, Huffam SE, Krause VL. Melioidosis epidemiology and risk factors from a prospective wholepopulation study in northern Australia. Tropical Med Int Health. 2004;9(11): 1167-74.

9. Limmathurotsakul D, Wongratanacheewin S, Teerawattanasook N, Wongsuvan G, Chaisuksant S, Chetchotisakd P, Chaowagul W, Day NPJ, Peacock SJ. Increasing incidence of human melioidosis in northeast Thailand. Am J Trop Med Hyg. 2010;82(6):1113-7.

10. Niyasom S, Sithinamsuwan P, Udommongkol C, Suwantamee J. Dural sinus thrombosis in melioidosis: the first case report. J Med Assoc Thail. 2006; 89(2):242-7.

11. Direksunthorn T. Melioidosis with portal vein thrombosis. Case Rep Infect Dis. 2017;2017:2891510.

12. Wiersinga WJ, Virk HS, Torres AG, Currie BJ, Peacock SJ, Dance DAB, Limmathurotsakul D. Melioidosis. Nat Rev Dis Primers. 2018;4:17107. 
13. Panginikkod S, Ramachandran A, Bollimunta P, Habibi R, Kumar Arjal R, Gopalakrishnan V. Burkholderia aortic aneurysm: a case report and review of the literature. Case Rep Infect Dis. 2017;2017:6206395.

14. Kim SW, Kwon G-Y, Kim B, Kwon D, Shin J, Bae G-R. Imported melioidosis in South Korea: a case series with a literature review. Osong Public Health Res Perspect. 2015;6(6):363-8.

15. Li PH, Chau CH, Wong PC. Melioidosis mycotic aneurysm: an uncommon complication of an uncommon disease. Respir Med Case Rep. 2015;14:43-6.

16. Rao J, Kaushal AS, Hoong CK. Abdominal aortic pseudoaneurysm secondary to melioidosis. Asian J Surg. 2009;32(1):64-9.

17. Muthusamy KA, Waran V, Puthucheary SD. Spectra of central nervous system melioidosis. J Clin Neurosci. 2007;14(12):1213-5.

18. Nayak R, Patel B, Raju K. Chronic pachymenigitis with dural venous sinus thrombosis: an unusual presentation of cranial melioidosis. Neurol India. 2018:66(4):1185-7.

19. Chong VH, Lim KS, Sharif F. Pancreatic involvement in melioidosis. J Pancreas. 2010;11(4):365-8.

20. Saïdani N, Griffiths K, Million M, Gautret P, Dubourg G, Parola P, Brouqui P, Lagier JC. Melioidosis as a travel-associated infection: case report and review of the literature. Travel Med Infect Dis. 2015;13(5):367-81.

21. Opal SM. Phylogenetic and functional relationships between coagulation and the innate immune response. Crit Care Med. 2000;28(9 Suppl):S77-80

22. Vervloet MG, Thijs LG, Hack CE. Derangements of coagulation and fibrinolysis in critically ill patients with sepsis and septic shock. Semin Thromb Hemost. 1998;24(1):33-44.

23. LaRosa SP, Opal SM, Utterback B, Yan SC, Helterbrand J, Simpson AJ, Chaowagul W, White NJ, Fisher CJ Jr. Decreased protein C, protein S, and antithrombin levels are predictive of poor outcome in gram-negative sepsis caused by Burkholderia pseudomallei. Int J Infect Dis. 2006;10(1):25-31.

24. Hernandez-Espinosa D, Ordonez A, Minano A, Martinez-Martinez I, Vicente V, Corral J. Hyperglycaemia impairs antithrombin secretion: possible contribution to the thrombotic risk of diabetes. Thromb Res. 2009;124(4): 483-9.

25. Kingsley PV, Leader M, Nagodawithana NS, Tipre M, Sathiakumar N. Melioidosis in Malaysia: a review of case reports. PLoS Negl Trop Dis. 2016; 10(12):e0005182.

\section{Publisher's Note}

Springer Nature remains neutral with regard to jurisdictional claims in published maps and institutional affiliations.

Ready to submit your research? Choose BMC and benefit from:

- fast, convenient online submission

- thorough peer review by experienced researchers in your field

- rapid publication on acceptance

- support for research data, including large and complex data types

- gold Open Access which fosters wider collaboration and increased citations

- maximum visibility for your research: over $100 \mathrm{M}$ website views per year

At $\mathrm{BMC}$, research is always in progress.

Learn more biomedcentral.com/submissions 